\title{
ІНВЕСТИЦІЙНА ПРИВАБЛИВІСТЬ ПІДПРИЄМСТВ: СУТНІСТЬ, ФАКТОРИ ВПЛИВУ, МЕТОДИЧНІ ПІДХОДИ
}

\author{
Роганова Г. О., кандидат економічних наук, \\ старший викладач кафедри фінансів Національного університету харчових технологій, \\ Україна
}

DOI: https://doi.org/10.31435/rsglobal_ijite/30062019/6531

\section{ARTICLE INFO \\ Received 25 April 2019 \\ Accepted 19 June 2019 \\ Published 30 June 2019 \\ KEYWORDS \\ інвестиції, інвестиційна привабливість, оцінка, підприємства харчової промисловості.} \begin{abstract}
Ефективне функціонування суб'єктів господарювання, їхній стійкий стан майже неможливі без здійснення інвестицій, оскільки саме інвестиції дозволяють досягати підприємствам подальшого розширення i розвитку виробництва; відновлення основних фондів, підвищення технічного рівня виробництва, відповідно, і конкурентоспроможності підприємства на ринку.

Стаття присвячена розв'язанню теоретичних, методичних та практичних проблем оцінки інвестиційної привабливості суб'єктів господарювання.
\end{abstract}

Citation: Rohanova H. O. (2019) Investytsiina Pryvablyvist Pidpryiemstv: Sutnist, Faktory Vplyvu, Metodychni Pidkhody. International Journal of Innovative Technologies in Economy. 4(24). doi: 10.31435/rsglobal_ijite/30062019/6531

Copyright: (C) 2019 Rohanova H. O. This is an open-access article distributed under the terms of the Creative Commons Attribution License (CC BY). The use, distribution or reproduction in other forums is permitted, provided the original author(s) or licensor are credited and that the original publication in this journal is cited, in accordance with accepted academic practice. No use, distribution or reproduction is permitted which does not comply with these terms.

Постановка проблеми. На даному етапі розвитку України питання залучення інвестицій в будь-яку сферу народного господарства $\epsilon$ надзвичайно важливим. Інвестиції займають ключову позицію в сприянні успішному економічному розвитку не тільки підприємства, а й економіки країни в цілому. Саме тому, правильне визначення інвестиційної привабливості суб'єкта господарювання є вкрай важливим і необхідним.

Формування інвестиційної привабливості підприємства необхідно для: забезпечення конкурентоспроможності продукції та підвищення іiі якості; структурної перебудови виробництва; створення необхідної сировинної бази для ефективного функціонування підприємств; вирішення соціальних проблем; інвестиції необхідні для забезпечення ефективного функціонування підприємств, їх стабільного стану та, у зв'язку з цим, вони використовуються для досягнення подальшого розширення та розвитку виробництва; відновлення основних виробничих фондів; підвищення технічного рівня праці та виробництва тощо [6]. Якісна і своєчасна оцінка інвестиційної привабливості суб'єктів підприємництва підвищує обгрунтованість управлінських рішень 3 питань галузевої i регіональної диверсифікованості інвестиційного портфелю підприємств, створює умови для здійснення більш ефективної їхньої інвестиційної діяльності [21, 369].

3 метою залучення зовнішніх інвестиційних ресурсів підприємство повинно відповідати ряду характеристик, які відображають внутрішні та зовнішні особливості його діяльності. Ці характеристики варто розуміти як сукупність факторів внутрішнього та зовнішнього середовищ, що являють собою інвестиційну привабливість підприємства $[1,155]$. Також, щоб підприємство було інвестиційно привабливим, воно, перш за все, повинно мати корпоративну форму власності, стабільне зростання показників діяльності та високий рівень корпоративного управління, що виражається, зокрема, через вартість акцій, динаміку ііі зростання. На жаль, вітчизняні підприємства частіше за все не відповідають даним вимогам, відчуваючи постійний 
брак власних фінансових ресурсів та працюючи із застарілими потужностями, що значно погіршує інвестиційний привабливість підприємства для інвесторів [6].

Аналіз останніх досліджень і публікацій. В економічній літературі проблеми сутності й аналізу основних підходів до оцінки інвестиційної привабливості висвітлено в цілому ряді робіт. Теоретичні питання визначення і дослідження інвестиційної привабливості підприємств промисловості розглядаються у роботах таких вітчизняних вчених: Вахович I.M [1], Гаврилова Н.В. [3], Горник В.Г. [4], Коробков Д.В. [5], Короткова О.В. [6], Косенко О. П. [7], Крамаренко К.М. [8], Кузьменко О. В. [9], Михайлова Л.І. [10], Овчаренко Т.С. [2], Олександренко І.В. [1], Рзаєв Г.І. [11], Ситник О.В. [12], Щербатенко I. [13] та інші.

Багато уваги визначенню рівня інвестиційної привабливості приділяють і закордонні вчені. Так, за допомогою факторного аналізу авторами статті [14] запропоновано інструменти вимірювання акціонерного капіталу 3 точки зору інвестиційної привабливості суб'єкта господарювання. На прикладі сектора харчових технологій Румунії у роботі [15] автором пропонується оцінка іноземних інвестицій та висвітлюються основні моменти інвестиційної привабливості підприємств для іноземних інвестицій. Використовуючи комплексний підхід у дослідженні [16], його автори здійснюють кількісну оцінку компонентів інноваційної стратегії суб'єкта господарювання, що дозволило їм зробити висновки щодо ії інвестиційної привабливості.

Метою дослідження $є$ надання власної дефініції інвестиційної привабливості підприємств та узагальнення наявних методик оцінки інвестиційної привабливості суб'єктів підприємництва.

Виклад основного матеріалу.

Сутність інвестиційної привабливості.

Інвестиційна привабливість суб'єктів господарювання, а також напрями ії підвищення $\epsilon$ предметом вивчення багатьох науковців. Проте нині не існує єдиної думки щодо суті цього поняття. Також відсутній єдиний погляд $\mathrm{i}$ щодо методики визначення інвестиційної привабливості підприємства $[8,101]$.

Нині вчені-економісти й економісти-практики не дають чіткого визначення сутності інвестиційної привабливості. Це підтверджується наданими авторами робіт [8, 102], [4], [17], [9, 48], [10, 64], [7, 131-132], [6] дефініціями, наведеними табл. 1. Проте ці трактування мають певні спільні риси. Так, по-перше, усі автори вважають, що інвестиційна привабливість характеризує об'єкт інвестування в цілому («узагальнююча характеристика», «інтегральний показник», «складне економічне поняття, яке має системний характер», «сукупність виробничо-фінансових кількісних i якісних умов та критеріїв», «інтегральна сукупність критеріїв»). По-друге, інвестиційна привабливість розраховується і розглядається кожним окремо взятим інвестором i характеризує переваги і недоліки інвестування, його умови, дієвість і т. п. [8, 101-102].

Таблиця 1. Розуміння сутності інвестиційної привабливості

\begin{tabular}{|l|l|}
\hline Автори & Трактування поняття «інвестиційна привабливість» \\
\hline \multicolumn{1}{|c|}{1} & \multicolumn{1}{c|}{2} \\
\hline $\begin{array}{l}\text { Горник В.Г, } \\
\text { Дацій О. І. }\end{array}$ & $\begin{array}{l}\text { узагальнююча характеристика, яка відображає всі переваги та недоліки для } \\
\text { інвестора в об’єкті інвестування }\end{array}$ \\
\hline Гуткевич С.О. & $\begin{array}{l}\text { узагальнююча характеристика переваг та недоліків інвестування окремих } \\
\text { напрямів та об’єктів із позиції конкретного інвестора }\end{array}$ \\
\hline $\begin{array}{l}\text { Загородній А.Г, } \\
\text { Вознюк Г. Л }\end{array}$ & $\begin{array}{l}\text { узагальнена характеристика переваг і недоліків інвестування окремих } \\
\text { об’єктів чи напрямів із погляду інвестора }\end{array}$ \\
\hline Короткова О.В. & $\begin{array}{l}\text { сукупність факторів, аналіз яких вказує на можливість вкладання коштів в } \\
\text { той чи інший об’єкт та отримання певного ефекту; інтегральна } \\
\text { характеристика підприємств з позиції перспектив розвитку, обсягу та } \\
\text { можливостей збуту продукції, ефективності використання активів та їх } \\
\text { ліквідності, стану платоспроможності і фінансової стійкості. }\end{array}$ \\
\hline $\begin{array}{l}\text { Косенко О. П, } \\
\text { Перерва П. Г, } \\
\text { Майстро Д. С }\end{array}$ & $\begin{array}{l}\text { відносне поняття, що відображає думку певної групи інвесторів відносно } \\
\text { співвідношення рівня ризику, рівня прибутковості і вартості фінансових } \\
\text { ресурсів в тій або інший державі, регіоні або галузі. 3 іншої сторони - це } \\
\text { сукупність деяких об'єктивних ознак, властивостей, засобів, можливостей } \\
\text { економічної системи, яка обумовлює потенційний платіжний попит на } \\
\text { інвестиції. }\end{array}$ \\
\hline
\end{tabular}


Продовження таблиці 1.

\begin{tabular}{|l|l|}
\hline \multicolumn{1}{|c|}{1} & \multicolumn{1}{c|}{2} \\
\hline Костюк Т. I & $\begin{array}{l}\text { складне економічне поняття, яке має системний характер, що виявляється в } \\
\text { комплексі правил та умов вкладання інвестиційних ресурсів у той чи інший } \\
\text { об’єкт у визначений час }\end{array}$ \\
\hline Крамаренко К.М. & $\begin{array}{l}\text { інтегральний показник, певна узагальнююча характеристика доцільності } \\
\text { інвестування визначеного об’єкта з позицій конкретного інвестора }\end{array}$ \\
\hline Кузьменко О. В. & $\begin{array}{l}\text { економічна характеристика, що відображає здатність залучати, освоювати } \\
\text { та використовувати інвестиції завдяки розвинутому інвестиційному } \\
\text { потенціалу та сприятливій регіональній інвестиційній політиці. }\end{array}$ \\
\hline Лайко Г. П & $\begin{array}{l}\text { сукупність виробничо-фінансових кількісних і якісних умов та критеріїв, } \\
\text { які характеризують іхні потенційні можливості та економічні переваги } \\
\text { порівняно з іншими об'єктами інвестування }\end{array}$ \\
\hline $\begin{array}{l}\text { Михайлова Л.І., } \\
\text { Майданевич П.М. }\end{array}$ & $\begin{array}{l}\text { сукупність умов (економічних, правових, політичних, соціальних та ін.), які } \\
\text { створено державою для всіх суб'єктів господарювання, а також іноземних } \\
\text { інвесторів, для вигідного вкладення інвестицій з метою розвитку } \\
\text { національної економіки в цілому та підприємств зокрема. }\end{array}$ \\
\hline $\begin{array}{l}\text { Саблук П., } \\
\text { Кісіль М., } \\
\text { Коденська М. }\end{array}$ & $\begin{array}{l}\text { інтегральна сукупність критеріїв дієвості умов інвестування, які } \\
\text { забезпечують особистий інтерес інвесторів до вкладення капіталу з метою } \\
\text { його примноження або отримання соціального ефекту }\end{array}$ \\
\hline Сталінська О. А & $\begin{array}{l}\text { інтегральний показник, об’єднуючий комплекс формалізованих і } \\
\text { неформалізованих критеріїв, що характеризує доцільність вкладення } \\
\text { капіталу в досліджуваний потенційний об'єкт інвестування }\end{array}$ \\
\hline Танделова О.М. & $\begin{array}{l}\text { об’єктивні передумови для інвестування і кількісно виражається обсягом } \\
\text { капітальних вкладень, які можуть бути залучені в регіон, виходячи з його } \\
\text { інвестиційного капіталу та рівня некомерційних інвестиційних ризиків, що } \\
\text { дозволяє досліджувати регіони в площині «потенціал - ризик». }\end{array}$ \\
\hline
\end{tabular}

Джерело: складено автором на основі дослідження джерел [8, 102], [4], [17], [9, 48], [10, 64], [7, 131-132].

Отже, 3 огляду на розмаїття тлумачень дефініції «інвестиційна привабливість» пропонуємо розглядати інвестиційну привабливість діючого суб'єкта підприємництва як інтегральний показник, що позитивно характеризує в динаміці сукупність показників фінансової звітності, конкуренто- та кредитоспроможності суб'єкта підприємництва, з метою максимізації прибутку інвестора та мінімізації ризиків у майбутньому.

\section{Фактори впливу на інвестиційну привабливість.}

Основним етапом формування інвестиційної привабливості підприємства є визначення факторів впливу на неї та їх класифікація, що сприяє кращому та більш повному розумінню самої сутності інвестиційної привабливості. Існує багато класифікацій даних факторів, так само як і думок стосовно того, які саме фактори впливають на інвестиційну привабливість. Автором роботи [6] було згруповано фактори впливу у дві групи: фактори опосередкованого впливу та фактори безпосереднього впливу підприємства на інвестиційну привабливість. До першої групи факторів відносяться ті, що не піддаються впливу окремого підприємства, тобто, на них можна впливати тільки на державному рівні (зовнішні фактори). До другої ж групи відносяться фактори, на які підприємство може впливати та змінювати їх показники, характеристики тощо (внутрішні). Автори роботи [13] об’єднали фактори впливу на інвестиційну привабливість суб'єкта господарювання на рівні галузі у 7 груп. Такий перелік факторів, які в різній мірі впливають на інвестиційну привабливість підприємств нами було ураховано при побудові схеми, зображеної на рис. 1 . 


\begin{tabular}{|c|c|c|}
\hline \multicolumn{3}{|c|}{ Фактори впливу на інвестиційну привабливість } \\
\hline 言 & $\begin{array}{l}\text { 1. Галузева приналежність } \\
\text { 2. Географічне розташування } \\
\text { 3. Наявність та доступність } \\
\text { 4. Положення на Світовому ринку } \\
\text { 5. Соціально-політична стабільність } \\
\text { 6. Економічна стабільність } \\
\text { 7. Контрольні державні органи } \\
\text { 8. Нормативно-правова база } \\
\end{array}$ & $\begin{array}{l}\text { 9. Інформаційне поле } \\
\text { 10. Пільги для інвесторів } \\
\text { 11. Економічна свобода } \\
\text { 12. Розвинута інфраструктура } \\
\text { 13. Темп інфляції } \\
\text { 14. Можливість експорту } \\
\text { 15. Рівень доходів населення }\end{array}$ \\
\hline 高 & $\begin{array}{l}\text { 1. Виробнича програма } \\
\text { 2. Маркетингова діяльність } \\
\text { 3. Управлінський облік та } \\
\text { 4. Стан майна та фінансових } \\
\text { 5. Кадровий потенціал } \\
\text { 6. Юридична діяльність } \\
\text { 7. Виробничі технології } \\
\text { 8. Стратегія розвитку } \\
\end{array}$ & $\begin{array}{l}\text { 9.Конкурентоспроможність } \\
\text { 10. Унікальність об'єкту } \\
\text { 11. Інвестиційна програма } \\
\text { 12. Платіжна дисципліна } \\
\text { 13. Корпоративне управління } \\
\text { 14. Витрати } \\
\text { 15. Структура капіталу }\end{array}$ \\
\hline 管 & $\begin{array}{l}\text { 1. Розмір та потенціал ринку } \\
\text { 2. Конкуренція } \\
\text { 3. Бар'єри входження до галузі } \\
\text { 4. Бар'єри виходу підприємства } 3 \\
\text { 5. Взаємовідносини } 3 \\
\end{array}$ & $\begin{array}{l}\text { 6. Технологічні фактори } \\
\text { 7. Стан основних фондів } \\
\text { 8. Рейтинг у галузі } \\
\text { 9. Можливості модернізації }\end{array}$ \\
\hline 寻 & $\begin{array}{l}\text { 1. Наявність місцевих і локальних } \\
\text { 2. Людські ресурси } \\
\text { 3. Нерівномірність регіонального } \\
\text { 4. Історичні фактори } \\
\text { 5. Демографічні ресурси } \\
\text { 6. Етнографічні фактори } \\
\text { 7. Природні ресурси }\end{array}$ & $\begin{array}{l}\text { 8. Підприємництво і міська влада } \\
\text { 9. Розвиток інфраструктури } \\
\text { 10. Психологія інвестора } \\
\text { 11. Потенційний економічний ризик } \\
\text { 12. Соціальні фактори } \\
\text { 13. Культура та освіта населення } \\
\text { 14. Екологічна ситуація }\end{array}$ \\
\hline
\end{tabular}

Рис. 1. Фактори впливу на інвестииійну привабливість

Джерело: складено автором на основі [6], [13]

Зовнішні фактори є набагато масштабнішими, а їх вплив $є$ більш суттєвим. Якщо інвестор бажає вкладати кошти в розвиток підприємства, то це не обов'язково має бути існуюче підприємство, може бути створено й зовсім нове підприємство. При цьому вагомим орієнтиром здійснення інвестицій є зовнішнє середовище підприємства і чинники, які його формують.

Інвестиційну привабливість підприємства можна визначати кількісно, що дозволить із декількох підприємств обрати саме те, яке є привабливим для потенційного інвестора $[1,156]$.

Оцінка інвестиційної привабливості.

Методики оцінки інвестиційної привабливості підприємства, напрями і методики ії аналізу залежать від мети оцінки, що обумовлена в першу чергу цілями, які поставив перед собою інвестор. У вітчизняній практиці науковці використовують різноманітні підходи оцінки інвестиційної привабливості, які визначають саме сутність методик, що застосовуються $[11,142]$. 
Комплексна оцінка інвестиційної привабливості повинна проводитись, виходячи 3 інтересів як самого підприємства, так й окремих груп інвесторів, які зацікавлені в ефективності вкладення коштів, та чітко визначати ступінь корисності реалізації проектів для всіх учасників процесу інвестування. Автором роботи $[11,143]$ пропонується всі розроблені методики оцінки інвестиційної діяльності умовно поділити на дві великі групи:

1) методи рейтингової оцінки підприємства на основі даних фінансової звітності підприємств;

2) інтегральна оцінка інвестиційної привабливості затверджена наказом 3 питань запобігання банкрутству підприємства. Остання методика є застарілою і потребує оновлення. Відповідно до характеристик, недоліків та переваг такого підходу було складено рис. 2.

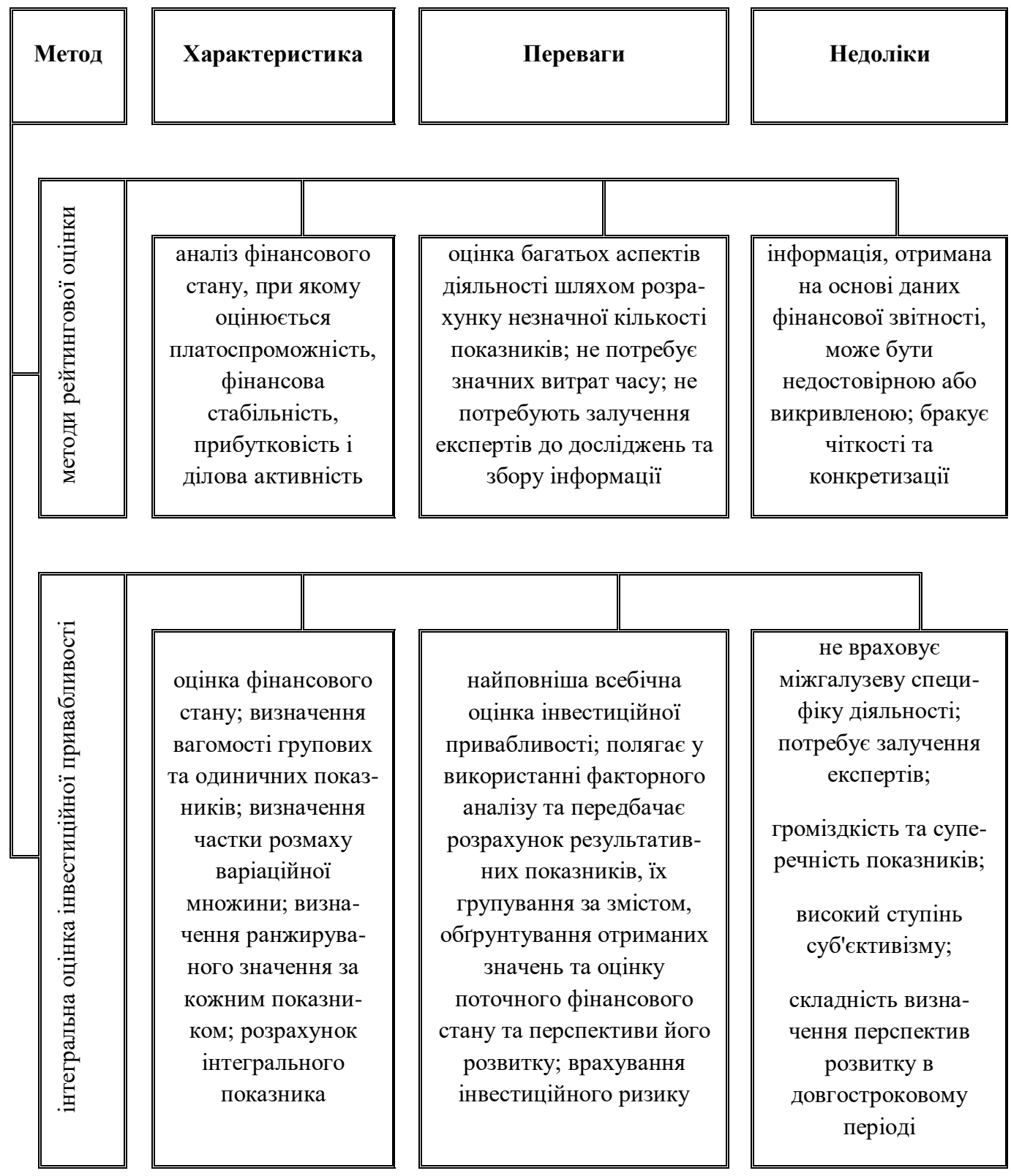

Рис. 2. Характеристика методів оцінки інвестиційної привабливості

Джерело: складено автором на основі [11]

Узагальнення даних рис. 2 дає змогу виділити методики, що грунтуються на оцінці фінансового стану в динаміці за даними звітності суб'єкта підприємництва. Більш деталізована інформація щодо методів оцінки наведена а Додатку Б, де зрозуміло, що найбільш поширеними $\epsilon$ методики, які грунтуються на фінансовому стані підприємства, тобто безпосередньо базуються на показниках фінансової звітності.

Комплексна оцінка інвестиційної привабливості повинна проводитись, виходячи 3 інтересів як самого підприємства, так й окремих груп інвесторів, які зацікавлені в ефективності 
вкладення коштів, та чітко визначати ступінь корисності реалізації проектів для всіх учасників процесу інвестування.

Для оцінки інвестиційної привабливості не слід зупинятися на одному методі оцінки, так як якісне оцінювання потребує врахування розширеної кількості критеріїв та підходів, які в комплексі дають змогу об'єктивно визначити ступінь інвестиційної привабливості підприємства на перспективу.

Автор роботи [2, 685] зазначає, що систематизація методичних підходів до оцінки інвестиційної привабливості формує три підходи: статистичний, експертний та рейтинговий. Визначимо їх основні характеристики у рис. 3. Такі підходи тісно перекликаються із методичними підходами, визначеними на рис. 2.

Отже, існує досить велика кількість методик оцінки інвестиційної привабливості, проте всім їм притаманні певні недоліки, а саме: більшість підходів заснована на аналізі певних показників фінансового стану підприємства, які не є систематизованими та носить ретроспективний характер, в той час як інвесторів цікавлять результати майбутньої діяльності. Багато методів запозичені в іноземних авторів і не адаптовані до умов вітчизняної економіки $[11,145]$.

\begin{tabular}{|c|c|c|c|}
\hline Підхід & Характеристика & Переваги & Недоліки \\
\hline 㿣 & $\begin{array}{c}\text { грунтується на аналізі } \\
\text { фактичних статистичних } \\
\text { даних стосовно } \\
\text { надходження інвестицій; } \\
\text { передбачає, що високий } \\
\text { рівень показників свідчить } \\
\text { про високу інвестиційну } \\
\text { привабливість }\end{array}$ & $\begin{array}{c}\text { охоплює максимальну } \\
\text { кількість економічних } \\
\text { характеристик та } \\
\text { показників; відсутність } \\
\text { суб’єктивізму; } \\
\text { базується на } \\
\text { конкретних } \\
\text { економічних } \\
\text { показниках }\end{array}$ & $\begin{array}{c}\text { метод носить } \\
\text { формалізований } \\
\text { характер; не } \\
\text { ураховує } \\
\text { галузеву } \\
\text { специфіку }\end{array}$ \\
\hline 恣 & $\begin{array}{c}\text { експерт з власних } \\
\text { міркувань і власного } \\
\text { досвіду обирає найбільш } \\
\text { важливі показники, } \\
\text { аналізує їх динаміку } \\
\text { розвитку та формує } \\
\text { висновки стосовно } \\
\text { інвестиційного клімату } \\
\end{array}$ & $\begin{array}{c}\text { можливість адаптації } \\
\text { показників і факторів } \\
\text { для потреб конкретних } \\
\text { інвесторів; } \\
\text { поглиблений аналіз } \\
\text { привабливості галузей; } \\
\text { привабливий для } \\
\text { іноземних інвесторів } \\
\end{array}$ & $\begin{array}{c}\text { суб'єктивність } \\
\text { оцінки; } \\
\text { залежність } \\
\text { висновків від } \\
\text { позицій } \\
\text { експерта }\end{array}$ \\
\hline 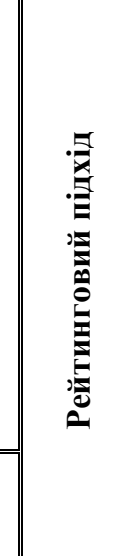 & $\begin{array}{l}\text { 1) рейтингово-аналітичний } \\
\text { метод полягає в аналізі } \\
\text { аспектів розвитку, } \\
\text { формуванні аналітичних } \\
\text { показників, їх групуванні і } \\
\text { формуванні інтегрально- го } \\
\text { показника, за яким далі } \\
\text { будується рейтинг. } \\
\text { 2) рейтинговий підхід на } \\
\text { основі опитувань суб’єктів } \\
\text { економічної діяльності або } \\
\text { експертів з визначенням } \\
\text { ступеню та напряму } \\
\text { впливу факторів. }\end{array}$ & $\begin{array}{c}\text { 1)охоплює велику } \\
\text { низку показників; } \\
\text { точний; ураховує } \\
\text { галузеві особливості; } \\
\text { 2)різноманітність } \\
\text { висновків; урахування } \\
\text { різноманітних } \\
\text { факторів }\end{array}$ & $\begin{array}{l}\text { 1)складний та } \\
\text { громіздкий, } \\
\text { 2)суб'єктивність } \\
\text { оцінки; } \\
\text { залежність } \\
\text { висновків від } \\
\text { позицій } \\
\text { опитуваних }\end{array}$ \\
\hline
\end{tabular}

Рис. 3. Систематизація методичних підходів до оцінки інвестиційної привабливості Джерело: складено автором на основі [2] 
Висновки 3 проведеного дослідження. Узагальнюючи результати, слід зазначити, що нині існує досить багато підходів до оцінки інвестиційної привабливості. Кожен підхід $є$ унікальним та має як переваги, так і недоліки.

Оцінка інвестиційної привабливості підприємств передбачає: здійснення аналізу фінансовогосподарського стану; визначення факторів, що впливають на інвестиційну привабливість; застосування оптимального методу визначення інвестиційної привабливість, якій максимально ураховує специфіку діяльності, його потенціал та відповідає цілям інвестування.

Доцільне інвестування дозволяє розширити виробничий потенціал підприємства, покращити стан основних фондів, підвищити якість продукції та конкурентоспроможність підприємства.

\section{ЛIТЕРАТУРА}

1. Вахович І.М. Методика оцінювання інвестиційної привабливості підприємства / І.М. Вахович, І.В. Олександренко, М.С. Забедюк // Актуальні проблеми економіки. - 2014. - №11. - С. 154-160.

2. Овчаренко Т.С. Методичні підходи щодо визначення інвестиційної привабливості галузей України / Т.С. Овчаренко, А.А. Степанова // Молодий вчений. - 2017 р. - №5(45). - С. 685-689.

3. Гаврилова Н.В. Фактори підвищення рівня інвестиційної привабливості підприємства / Н.В. Гаврилова // Наукові праці Кіровоградського національного технічного університету. Економічні науки. - 2011. - Вип. 20, ч. II. - С. 324-330.

4. Горник В.Г. Інвестиційно-інноваційний розвиток промисловості: монографія / В.Г. Горник, Н.В. Дацій. - К.: Вид-во НАДУ, 2005. - 200 с.

5. Коробков Д.В. Інвестиційна привабливість підприємств енергетичної галузі [Електронний ресурс] / Д.В. Коробков. - 2006. - Режим доступу: http://www.kpi.kharkov.ua/

6. Короткова О.В. Інвестиційна привабливість підприємства та методики їі оцінювання [Електронний ресурс] / О. В. Короткова // Ефективна економіка. - №6. - 2013. - Режим доступу: http://www.economy.nayka.com.ua/

7. Косенко О.П. Інвестиційна привабливість як економічна [Електронний ресурс] / О.П. Косенко, П.Г. Перерва, Д.С. Майстро. - Режим доступу: http://repository.kpi.kharkov.ua/

8. Крамаренко К.М. Інвестиційна привабливість підприємства та методичні підходи до ії визначення/ Крамаренко К.М. // Причорноморські економічні студії. - Вип. 10. - 2016. - С. 101-104.

9. Кузьменко О. В. Інвестиційний клімат та інвестиційна привабливість регіонів України / О.В. Кузьменко // Економічний нобелівський вісник. - 2015. - №1(8). - С. 46-54.

10. Михайлова Л.І. Теоретико-методологічні засади формування інвестиційної привабливості підприємств аграрної сфери / Л.І. Михайлова, П.М. Майданевич. // Вісник ХНАУ ім. В.В. Докучаєва. - 2014. - № 4. - С. 61-72.

11. Рзаєв Г.І. Методичні підходи оцінки інвестиційної привабливості підприємства / Г. І. Рзаєв, В. О. Вакулова // Вісник Хмельніцького національного університету. Економічні науки. - 2016. - №1. - С. 141-149.

12. Ситник О.В. Економічна сутність інвестиційної привабливості підприємства та ії характеристики / О. В. Ситник // Інвестиції: практика та досвід. - 2015. - №23. - С. 127-130.

13. Щербатенко I., Горбачова О. Аналіз факторів, що впливають на інвестиційну привабливість підприємств авіатранспортної галузі / І. Щербатенко, О. Горбачова // Економічний аналіз. - 2013. T. 12(4). - C. 166-170.

14. Sunny Bose, Sanjit Kumar Roy \& Abhay Kumar Tiwari. Measuring customer-based place brand equity (CBPBE): an investment attractiveness perspective / Sunny Bose, Sanjit Kumar Roy, Abhay Kumar Tiwari. // Journal of Strategic Marketing. - Vol. 24, 2016 - Issue 7. https://doi.org/10.1080/0965254X.2016.1148766

15. Stanciu, Silvius T. The romanian food sector attractiveness for foreign investment / Silvius T. Stanciu // Practical Application of Science. - 2014, Vol. 2 Issue 3. - pp. 603-610.

16. Rolic Y. A Complex Approach to Evaluating the Innovation Strategy of a Company to Determine its Investment Attractiveness / Y.A. Rolic // Procedia - Social and Behavioral Sciences. - 2013, Vol. 99, pp. 562-571. https://doi.org/10.1016/j.sbspro.2013.10.526

17. Танделова О.М. Инвестиционная привлекательность регионов России [Электронный ресурс] / О. Танделова. - Режим доступа: http://refoteka.ru/r-100875.html

18. Річна фінансова звітність [Електронний ресурс]. - Режим доступу: smida.gov.ua

19. Капітальні інвестиції в Україні у 2010-2015 роках: статистичний збірник: Державна служба статистики України. - Київ, 2016. - 115 с.

20. Щербіна А. Підвищення інвестиційної привабливості українських підприємств як чинник стабілізації економічної ситуації в Україні: Economic and law paradigm of modern society. 2016. - №1. - Режим доступу: http://studlib.org.ua/index.php/eprs/issue/view/1

21. Роганова, Г.О. Оцінка інвестиційної привабливості Донецького регіону / Г.О. Роганова Г.О. // Проблемы развития внешнеэкономических связей и привлечения иностранных инвестиций: региональный аспект. Сборник научных трудов. Донецк: ДонНУ, 2004. - С. 369-372. 